\title{
The Characteristics of Practice Teaching and Reform Measures in Higher Agricultural Colleges
}

\author{
Chunbo Wei ${ }^{1, a}$, Ying Zhang ${ }^{1, b}$,Changping Wang ${ }^{1, c}$ \\ ${ }^{1}$ College of Animal Science and Technology, Hei Longjiang Bayi Agricultural University, \\ Hei Longjiang, daqing 163319; \\ ${ }^{2}$ College of Life Science, JIA MU SI University, Hei Longjiang, JIA MU SI 154007 \\ achunbowei@byau.edu.cn, byingzhang@byau.edu.cn, cWcp100200@163.com
}

Key words: higher agricultural colleges, practice teaching, characteristics, reform

Abstract: The thesis is based on the study of the practice teaching of higher agricultural colleges in China as the starting point, probing into the present situation and the development trend of the practice teaching of higher agricultural colleges. Then the characteristics of practice teaching in higher agricultural colleges, are scientifically and systematically analyzed and on the basis of that the relevant measures are put forward in order to provide beneficial reference for practice teaching reform of higher agricultural colleges.

\section{Introduction}

Practice teaching is an important link of university personnel training in higher agricultural colleges. The core of the teaching is concerned with the cultivation of students' comprehensive professional knowledge to solve practical problems; the teaching goal is to develop students' innovative consciousness and practical ability, which is to improve the students' comprehensive quality, playing a special role in promoting the full-scale development of the students as for virtue, intelligence, physique and labor education. The Administrative Department of Education in our country has launched a series of major reform measures and national educational reform leading group, in accordance with the "top-level design, pilot first, steady progress" principle, comprehensively advances the overall pattern of education reform in our country; and in "Opinions On Deepening the Reform of Systems and Mechanisms to Speed Up the Implementation of Innovation-Driven Development Strategy of" clearly claims to "build an innovative talent training mode" and requires that colleges and universities perfect curriculum, strengthen the entrepreneurial practice, making efforts to improve college students' entrepreneurship and entrepreneurial ability. This requires the constant change of higher agricultural education mode to cultivate high-level, agricultural technology talents who possess the practical and innovative ability in a positive sense[1]. But how to construct practice teaching system scientifically and reasonably has become the major issues which higher education workers need to solve. Therefore, the author studied our country present situation and the development trend of the practice teaching of higher agricultural colleges in depth; on this basis, the systematic analysis of the characteristics of practice teaching in higher agricultural colleges as well as the basic principles the construction of practical teaching system should follow has been done aiming to provide beneficial guidance and teaching management for scientifically construct practical teaching system in higher agricultural colleges.

\section{The Characteristics of Practice Teaching in Higher Agricultural Colleges}

Higher agricultural colleges as an important part of higher education in our country, involves the agriculture science and related majors as the main body of comprehensive agricultural colleges, responsible for modern agriculture senior personnel training, reserves and output as the base; also for our country's agricultural modernization providing powerful technology and talent, having a distinct industry characteristics and playing a positive role in promoting social progress and economic development. The practice teaching is an vital part of higher agricultural teaching activities, having the effect that can not be replaced by other forms of teaching[2], The analysis and research of agricultural professional practice teaching characteristics are conducted in a systematic and the comprehensive way so that the organization and management work concerning the practice teaching can be targeted and carried out, which has the extremely important guiding significance. Compared 
with the theory of classroom teaching and other teaching activities, practice teaching characteristics of higher agricultural colleges are mainly embodied in the following several aspects:

\subsection{The Teaching of Practice Teaching}

Teaching is the attributes of practice teaching. On the condition that the students have a certain theoretical knowledge and under the guidance of the teachers, the combination of a series of teaching activities is taken into account through practical operation and the integrated application of professional knowledge in production to analyze and solve practical problems, so as to get perceptual knowledge and basic skills, which finally can improve students' comprehensive quality. The teaching of practice teaching is manifested in the process of practice teaching with teaching goal, teaching content, teaching form, teaching conditions, teaching assessment well planned and managed.

\subsection{The Professionalism of Practice Teaching}

Practice teaching of higher agricultural colleges must be based on the social demand for talent, combined with the characteristics of various professional fields; for instance, the central task of seed science and engineering is to cultivate talents who are expert in seed cultivation, processing, storage, testing, marketing and in related fields of basic theory and basic skills. And as for the cultivation of professional talented people in animal science, it is required to know and master the genetic and breeding of livestock, breeding, nutrition, management, life and so forth to supply more good quality animal products for humans. Thus, the diversity of agricultural engineering is indispensable; its practice teaching system should also embody the distinctive professionalism to show the targeted industries of practical teaching activities in higher agricultural colleges.

\subsection{The Application of Practice Teaching}

Under the background of practical teaching reform in higher agricultural colleges, more attention is given to the students' practical ability[3]. Practice teaching has become an important teaching method to cultivate applied talents, especially for agronomy class in the undergraduate education; it plays irreplaceable special role in improving the comprehensive quality of students and cultivating students' innovation spirit and practice ability[4]. It is fully realized that practice teaching has the important position in talent training, enhancing the application as the core of the practice teaching, actively exploring the reform mode of practice teaching, regarding the students' technical application ability as the key social need. The goal is to cultivate gradually students' innovation consciousness and entrepreneurial quality to improve their practice ability and level in the process of application of practice teaching

\subsection{The Labor of Practice Teaching}

Practice teaching is a process of mental labor and physical labor. Its labor is embodied in labor practice as a kind of teaching characteristics, which is more prominent especially in the practical teaching links of higher agricultural colleges. The main function of practice teaching is the application of major theoretical knowledge into practice, the master of the production skills, the adoption of the scientific method with problems found, analyzed and solved so as to improve the students' social practice ability and practice ability.

\section{The Reform of Practice Teaching in Higher Agricultural Colleges}

\subsection{Building Practice Education Concept from the Scientific View}

Talent cultivation of higher agricultural colleges should be guided by social needs, completely changing traditional education idea of "attaching much more importance to the theory than to practice," constantly innovating practice teaching system, adhering to the concept of practical education. Through the scientific formulation and implementation of teaching plan practice, teachers can train students' practical ability, to analyze and solve practical problems, develop innovative consciousness and cooperative spirit. For undergraduate professionals in animal husbandry, the first task is the scientific and reasonable allocation of the proportion of theory teaching and practice teaching; the weight of the practice teaching is increased; practice teaching accounts for not less than $30 \%$ of the total period so as to ensure the smooth progress in practice teaching for learning hours. Secondly, building the curriculum system to meet the needs of social practice and training professionals to ensure perfect knowledge structure in view of animal husbandry are also needed.

\subsection{Making Clear Teaching Training Goal}

There has been the idea of "valuing theory, much more than practice[5]" in the process of practice teaching. To break the shackles of the mind and to better improve the students' practical ability, the 
first question is making clear the direction of practice teaching and the target. Therefore, take animal husbandry and engineering practice teaching for example: its training goal is to develop high-quality skilled professionals who should have the basic skills of animal production, adapt to the modern animal husbandry development needs, are able to complete technical work such as livestock and poultry breeding, feed preparation, well-bred breeding health and so on. Also, they have the ability of organization and management, social adaptation ability and innovation ability, cultivating high-quality skilled professionals such as technical backbone for the modern animal husbandry enterprises, technical services and farms.

\subsection{Constructing Practice Teaching Course System Scientifically}

To strengthen the practice teaching reform, to establish and perfect the practice teaching system, the inevitable requirement of cultivating innovative talents in colleges and universities is designing and building a scientific and reasonable practical teaching curriculum system. Therefore, on the basis of extensive research and comprehensive analysis of the talent cultivation as for undergraduate professionals in animal husbandry in higher agricultural colleges and the distribution of graduates employment-oriented positions, scientific planning and top-level design concerning practical teaching course system and operational mechanism are made. Practical teaching links of undergraduate animal husbandry in higher agricultural colleges usually includes course experiment, professional cognition practice, course practice, production practice, graduation practice, professional skills training, scientific research ability training, etc.. On this basis, various practice teaching modes and methods are implemented and the integration of theory and practice of practice teaching should be integrated according to the demand characteristics of animal husbandry talent and college practice conditions to further perfect the practice teaching course system; various forms of practice teaching are flexible used such as the trinity practice system of "student + school + enterprise", and the four-in-one practice system "internship students + school + base + enterprise".

\subsection{Developing Practice Teaching Base Vigorously}

Practice teaching base is of great importance for the conduct of the practice teaching and social service and support, undertaking to train students' practical ability, innovation ability and to implement all-around education serving as the important material guarantee. The development of practice teaching base of animal husbandry mainly involves two aspects: one is the reasonable and efficient use of campus practice teaching resources to build a high level of experiment practice teaching platform. According to the animal husbandry and engineering practice teaching requirements, integrating college internal resources and building a comprehensive, multidisciplinary practice teaching management platform to make possible the unified management, unified construction, resources sharing, efficient use in accordance with the subject or experimental function category; the other is to make full use of social teaching resources, promoting the building of campus practice teaching base, integrating the cooperative education between colleges and enterprises, providing necessary support and guarantee for students keeping close contact with the production practice[6]. Animal husbandry professional off-campus practice base mainly concentrates on large and medium-sized farms, feed company, pasture company, veterinary medicine, animal husbandry research institutes, etc.; therefore, college-enterprise co-building, optimize configuration, resource sharing, developing professional training mode to meet the demand of industry, industry development and demand of animal husbandry talents can finally realize the training goal to cultivate applied talents between colleges and enterprises.

\subsection{Establishing a Scientific Practice Teaching Quality Evaluation System}

Students practice ability is the comprehensive ability of applying theoretical knowledge to practice; the practice of the traditional teaching appraisal way cannot really reflect the students' operating ability, analysis ability and level of creativity and so on, which can't make scientific evaluation to the practice teaching effect either. Therefore, it is necessary to establish an effective, systematic and comprehensive practice teaching evaluation system. Practice teaching quality evaluation should follow the rules of education teaching combined with the actual situation of animal husbandry and engineering teaching, adhering to the practice and application ability as the core of evaluation principles and the combined valuation principle "process evaluation plus practice results". First of all, in order to realize the diversity of evaluation subject, the main body of evaluation from multiple perspectives should be adopted, that is, the practice guidance teachers, experiment teachers, teaching supervisors, students all might as well participate in the evaluation. Second, the diversification of evaluation approach is a must according to the nature of the animal husbandry and professional 
practice courses by applying a variety of ways such as flexible experiments, practical skills, written examination, oral examination, practical paper which will be assessed throughout the entire teaching process. Again, the adoption of the combination of quantitative and qualitative comprehensive evaluation method according to the practice in the process of the diversity of main body and the diversification of practice, is bound to evaluate objectively and comprehensively the quality of practice teaching through the quantitative and qualitative analysis.

\section{Conclusion}

Practice teaching is an important part of teaching process in higher agricultural colleges especially under the background of the innovation-driven agricultural modernization in our country; in the process of developing professional talents as for animal husbandry, the practice teaching becomes even more important. Practice teaching reform is not only the demand of higher agricultural colleges to pursue undergraduate professional development in animal husbandry, but the demand of society for animal husbandry science and technology talents also. Through the demand analysis of the present situation and the society training for professional talents in higher agricultural colleges, the problems in the process of practical teaching regarding the animal husbandry undergraduate are more objectively analyzed, and reform measures are put forward in the practice teaching so as to provide the beneficial reference to the training of professional animal husbandry talents in higher agricultural colleges.

\section{Acknowledgements}

This work was financially supported by Hei Longjiang Provincial Education Science (GBC1212056), by the "twelfth five-year" plan key project of Hei Longjiang Provincial Education Science (GJB1215054) and Hei Longjiang Bayi Agricultural university research project "The Practice Teaching Mode Reform and Exploration in Higher Agricultural Colleges".

\section{References}

[1]Y.Wang, H.Q.zhang, K.H.Chen, et al:Journal of education teaching forum,Vol.7 (2015), p177-178.

[2] S.N. Zhang, W.Wang:Journal of industry, science and technology forum, Vol.12 (2011), p149-150.

[3]Y .Tang : Journal of Kaifeng institute of education, Vol.11(2014).p80-81.

[4] W. B. Zhu, H.X. Liu, W.Z Ma:Journal of Anhui agricultural science, Vol.7(2010),p3854-3856.

[5] N.Li , F.Jia, Y.Han:Journal of university education, Vol.1(2015),p16-19.

[6] X.B.Han: Journal of management and obserbation, Vol.24(2014),p:136-137.

\section{Author Introduction}

The first author: ChunBo Wei , 1977, male, lecturer; major study field: livestock production management and animal welfare, e-mail: chunbowei@byau.edu.cn.

Corresponding author: Changping Wang, e-mail:Wcp100200@163.com. 